\title{
Fair is as fair does: contractual normative regulation of copyright user contracts in South Africa
}

\author{
Caroline B Ncube
}

This draft chapter has been published by Edward Elgar Publishing in GB Dinwoodie (ed) Intellectual Property and General Legal Principles:Is IP a Lex Specialis? (2015)

Edward Elgar 49-68

Available at ElgarOnline

It is archived in accordance with Edward Elgar's Self Archiving and Personal Use Policy

\section{INTRODUCTION}

This chapter considers the regulation of copyright user contracts by contract and consumer protection law in South Africa. The normative regulation of copyright contracts was identified as a significant research gap by Kretschmer et al., who specifically list the following questions as being worthy of investigation: ${ }^{1}$

- How should 'fairness' be defined for the context of copyright contracts?

- $\quad$ Are existing contracts really 'unfair'?

- Do alternative contracts, within the current copyright law, exist that can be perceived as being 'fairer'? If they do exist, do those contracts sacrifice efficiency?

- To what extent does any perceived 'unfairness' depend upon copyright law?

- Can copyright law be altered in order that the balance of bargaining positions be changed and the resulting contracts are 'fair'?

This chapter engages with some of these questions, which will be posed with regard to user contracts for the reprographic reproduction of copyright-protected works concluded between copyright-holders (represented by a reprographic rights organisation) and higher educational institutions. Here, the main concern is whether such blanket or transactional licenses override statutory exceptions and limitations. If so, is this fair? If it is not fair, how may copyright law be amended to ensure fairness?

\footnotetext{
${ }^{1}$ Martin Kretschmer, Estelle Declaye, Marcella Favale and Richard Wyatt, The Relationship between Copyright and Contract Law (2010) 9 and 28.
} 
The key methodology will be doctrinal. The discussion will unfold within an access to knowledge framework, which seeks an equitable treatment of copyright-holder and user interests based on the public interest and constitutional principles. Specifically it will focus on how a lack of fairness or equity would fall foul of consumer protection legislation and thwart South Africa's constitutional imperative to provide education for its citizenry.

Copyright law frames the contracting space in which a copyright-holder contracts with third parties. It endows the copyright-holder with exclusive rights, which he can then license to users. ${ }^{2}$ As noted by Derclaye and Favale, ${ }^{3}$ these rights are limited by eligibility ${ }^{4}$ and substantive ${ }^{5}$ criteria for protection, the exclusion of certain works from copyright protection, ${ }^{6}$ the limited duration of copyright, the exhaustion of rights and exceptions and limitations. Exceptions and limitations provide users with limited permission and royalty-free uses of copyright-protected works. Both user and copyright-holder then negotiate a contract for use of the work that exceeds usage covered by exceptions and limitations. It is in this contracting space that fairness needs to be achieved. Moreso when contracts seek to erode existing permissible uses and to thus expand the right-holders monopoly in an environment where digital distribution is widespread. ${ }^{7}$

To the extent that copyright law defines the baseline for both right-holders and users, it is a lex specialis. The delimitation of the right-holder's exclusive rights and the exceptions and limitations upon which a user can rely are the domain of this body of law. General contractual principles are relevant to the extent that they regulate the conduct of both parties in the negotiation and conclusion of a copyright contract. Additionally, as discussed below, consumer protection legislation is also applicable.

As a precursor to this discussion, a brief overview of reprographic licensing in South Africa is given.

\footnotetext{
2 Niva Elkin-Koren, 'Copyright Policy and the Limits of Freedom of Contract', (1997) 12 Berkeley Tech. L.J. 93, 105.

${ }^{3}$ Estelle Derclaye and Marcella Favale, 'User Contracts' in Martin Kretschmer et al The Relationship between Copyright and Contract Law (2010) 71, 71.

${ }^{4}$ Section 2 (1) of the Copyright Act provides for the following exhaustive list of copyright-eligible subject matter: (1) literary, musical and artistic works; (2) cinematograph films; (3) sound recordings; (4) broadcasts; (5) programme-carrying signals; (6) published editions and (7) computer programs.

${ }^{5}$ Copyright will subsist automatically in eligible works if the three requirements for protection are met, namely that the work is reduced to a material form (ss 2(2)-2(2A)) and is created by a qualified person (ss 3(1) and 37) or is first published in South Africa or another country to which protection is extended (ss 4(1) and 1(5)).

${ }^{6}$ See for example s (8) (a), which provides: 'No copyright shall subsist in official texts of a legislative, administrative or legal nature, or in official translations of such texts, or in speeches of a political nature or in speeches delivered in the course of legal proceedings, or in news of the day that are mere items of press information.'

${ }^{7}$ Elkin-Koren (supra note 2) 113.
} 


\section{REPROGRAPHIC RIGHTS LICENSING IN SOUTH AFRICA}

The only reprographic rights organisation in South Africa is the Dramatic, Artistic and Literary Rights Organisation (DALRO). It is a member of both the International

Confederation of Copyright Societies (Confédération Internationale des Sociétés d'Auteur et

Compositeur) (CISAC) and the International Federation of Reproduction Rights

Organisations (IFRRO). DALRO states that its main mandate is the administration of 'reprographic reproduction rights (from published editions), public performance rights

(including stage rights for book musicals and dramas) and reproduction rights (granted for both publishing and copying) in works of visual art' ${ }^{8}$

DALRO issues two types of reprographic reproduction rights licenses, namely blanket and transactional licenses. The Universities of Cape Town, Stellenbosch and the University of the Witwatersrand have entered into blanket licenses with DALRO. These licenses permit licensees to make the copies it requires over an agreed period, after which the licensee reports on the copies made. Licensees are required 'to pay a once off invoice before the end of May each year'. ${ }^{9}$ No additional payment will be required provided the blanket license copying parameters are maintained. These parameters limit copying up to a maximum of one chapter or 10 per cent of a book; one article from a journal issue; a full case study and a full law report. ${ }^{10}$ Copying more than 10 per cent of a book will fall within the parameters if it consists of one full chapter. ${ }^{11}$ Where a licensee wishes to copy more than these parameters, DALRO would negotiate licensing with South African publishers, but where the publisher is foreign the licensee has to negotiate with that publisher directly. ${ }^{12}$ Of concern to this chapter is whether these parameters adequately take exceptions and limitations for educational purposes into account. The DALRO explanatory guide asserts that they have been taken into account. ${ }^{13}$ This point is addressed further below in the section entitled 'Fairness under copyright law'.

\footnotetext{
8 DALRO 'About us' <http://www.dalro.co.za/index.php/about-us> (last accessed 8 November 2013).

${ }^{9}$ University of the Witwatersrand 'Blanket License agreement with DALRO

$<$ http://libguides. wits.ac.za/content.php?pid=227586\&sid=2361879> (last accessed 8 November 2013).

${ }^{10}$ Ibid. Cape Higher Education Consortium (which administers licenses for universities in the Western Cape province of South Africa) User Manual: The Request Process

$<$ http://plo.uct.ac.za/help/user/usr_00_main.php > (last accessed 8 November 2013).

11 DALRO Information Brochure March 2013, 5.

< http://www.dalro.co.za/index.php/repository/Downloads/DALRO-Information-Brochure/> (last accessed 8

November 2013).

12 Ibid.

13 DALRO Reprographic Reproduction of Copyright Material for Educational Purposes (undated) < http://www.wsu.ac.za/library/DALRO.pdf > (last accessed 8 November 2013).
} 
Transactional licensing, used by the University of Pretoria, ${ }^{14}$ is described by DALRO as 'a pay-per-use service where institutions, businesses, schools and organisations pay for the re-use of specific selections. These selections are: a specific published work to be distributed to a specific group of people enrolled in a specific course or workshop held at a specific time. ${ }^{15}$ DALRO's 2013 rates for higher education institutions were ZAR0.63 per page and are significantly lower for state secondary and primary schools. ${ }^{16}$

Both licenses are administered through a copyright clearance system that has been put in place to facilitate this. Details of its implementation are available on the websites of several institutions. ${ }^{17}$ In the financial year ending 30 June 2010 DALRO collected license and royalty revenue for reprographic reproduction of ZAR26 $842183 .^{18}$

\section{FAIRNESS UNDER COPYRIGHT LAW}

There are several ways to rationalise copyright law, such as natural justice, economic, cultural and social arguments. ${ }^{19}$ Whatever one's philosophical persuasion, it is indisputable that one of the purposes or aims of copyright law, since its inception, is to serve the public interest. This purpose requires a balance between right-holder and user interests, particularly those underpinned by fundamental freedoms or public policy. As noted by Helfer and Austin: ${ }^{20}$

Conceptually and textually, there exist venerable connections between education and intellectual property. These connections are particularly clear in the copyright context ... The first copyright statute, the English Statute of Anne of 1709, was entitled 'An Act for the Encouragement of Learning.' Similarly, the Copyright Clause of the U.S. Constitution empowers the U.S. Congress to 'to promote the progress of science' (or, in modern parlance,

\footnotetext{
${ }^{14}$ University of Pretoria 'How to apply for copyright permission' $<$ www.ais.up.ac.za/copyright/permission.htm > (last accessed 8 November 2013).

15 DALRO 'Copyright Access for Institutions of Higher Learning: Transactional Licenses' $<$ http://www.dalro.co.za/index.php/lincences> (last accessed 8 November 2013).

16 DALRO 'Default rates April 2013'

< http://www.dalro.co.za/index.php/repository/Downloads/DEFAULT-RATES-APRIL-2013/> (last accessed November 2013).

${ }^{17}$ University of the Witwatersrand (supra note 7), the University of Pretoria (Transactional License) <http://www.ais.up.ac.za/copyright/permission.htm>. The University of Cape Town, University of the Western Cape, Cape Peninsula University of Technology and the University of Stellenbosch use the Cape Higher Education Consortium's Public Liaison Office's Copyright Clearance System < http://plo.uct.ac.za/user.php> (all last accessed 8 November 2013).

18 DALRO 'About us'<http://www.dalro.co.za/index.php/about-us> (last accessed 8 November 2013).

${ }^{19}$ Tana Pistorius, 'Copyright Law' in Hennie Klopper et al., The Law of Intellectual Property in South Africa (Lexis Nexis 2011) 143 at 144.

${ }^{20}$ Laurence R Helfer and Graeme W Austin, Human Rights and Intellectual Property: Mapping the Global Interface (Cambridge Univ. Press 2011) 316.
} 
'knowledge') by creating a national copyright system. In the early years of the French

Revolution, responsibility for the development of copyright law passed to the 'Committee for

Public Instruction,' and by 1793, it was accepted that 'enacting a copyright law formed part

of a grander scheme of public education'.</quotation>

The Berne Convention, $1886^{21}$ out of this understanding of the need to balance contesting stakeholder interests in the public interest, provides for exceptions and limitations to secure unremunerated user access to protected works in specified circumstances. ${ }^{22}$ In addition, it provides that member states may permit certain exceptions to the reproduction right subject to the so-called three-step test. ${ }^{23}$ This provision has been broadened to apply to other exclusive rights in more recent intellectual property (IP) agreements, namely article 13 of the Agreement on Trade Related Aspects of IP Rights (TRIPS) ${ }^{24}$ and article 10 of the World IP Organisation (WIPO) Copyright Treaty (WCT) ${ }^{25}$ Fairness and the balancing of interests are therefore often said to be a fundamental concern of this body of law. However, using the metaphor of balance raises several vexed questions, which have been discussed by several scholars. ${ }^{26}$ For present purposes it will suffice to mention three of these. First, what exactly does the concept mean or entail? Secondly, which measure should be used to gauge such balance $?^{27}$ Thirdly, even if one knows what it means and how to measure it, how is it to be attained on international and domestic levels? ${ }^{28}$ In some instances, the concept of balance is often used without full appreciation of its complex and 'multidimensional nature'. ${ }^{29}$ In relation to the second aspect, I have suggested elsewhere that 'the twin pillars of human rights and socio-economic conditions could be used to attempt to break the deadlock between

\footnotetext{
${ }^{21}$ Berne Convention for the Protection of Literary and Artistic Works, 9 September 1886, amended 28 September 1979, Art 2bis, 1161 UNTS 3 (Berne Convention).

22 Daniel J Gervais, 'Making copyright whole: a principled approach to copyright exceptions and limitations' 2008 University of Ottawa Law \& Technology Journal 1.

${ }^{23}$ Berne Convention, Article 9(2). For a discussion of the three-step test see Gervais (supra note 22) and Martin Senftleben, Copyright, Limitations, and the Three-step Test: An Analysis of the Three-step Test in International and EC Copyright Law (2004); Martin Senftleben, 'The International Three-Step Test A Model Provision for EC Fair Use Legislation' 1 (2010) JIPITEC 67, para. 1.

${ }^{24}$ Agreement on Trade-Related Aspects of Intellectual Property Rights, including Trade in Counterfeit Goods, adopted 15 December 1993, entered into force 1 January 1995, (1994) 33 ILM 81.

${ }^{25}$ WIPO Copyright Treaty, adopted 20 December 1996, entered into force on March 636 ILM 65.

${ }^{26}$ For example see William Patry, How to Fix Copyright (Oxford Univ. Press 2010) 134 -140; Graeme B Dinwoodie 'The WIPO Copyright Treaty: A Transition to the Future of International Copyright Lawmaking?' (2007) 57 Case Western Reserve Law Review 751; Abraham Drassinower 'From Distribution to Dialogue: Remarks on the Concept of Balance in Copyright Law' (2008-2009) 34 Journal of Corporation Law 991.

27 Carys J Craig, 'The Evolution of Originality in Canadian Copyright Law: Authorship, Reward and the Public Interest' (2005) 2 U. Ottawa L. \& Tech. J. 425, 441.

28 Dinwoodie (supra note 26) 753.

29 Dinwoodie ibid. For other discussions see also Patricia Akester, 'The New Challenges of Striking the Right Balance Between Copyright Protection and Access to Knowledge, Information and Culture', (2010) 32:8 European Intellectual Property Review 372.
} 
creators and users' interests' ${ }^{30}$ Another concern raised by using this metaphor is its tendency to distill the interests at stake into two sides, namely right-holders and users, which raises the risk of overlooking the highly nuanced positions of those who fall into neither group. ${ }^{31}$ In particular, the interests of users are distinct from of society generally as are the interests of authors and creators from intermediaries, and publishers who may hold copyright in the works in question. Further, the interests of members of each of these constituencies are diverse. For example not all users have the same interests. Indeed the balance metaphor has been dismissed as a 'fallacy' ${ }^{32}$ and suggestions have been made for its replacement with other turns of phrase. ${ }^{33}$ In view of these considerations, this chapter uses the concept of balance whilst acknowledging its limits.

The other rhetorical device used in this chapter - that of the 'public interest' - is also used advisedly because it is similarly fraught and has been critiqued for being vague. ${ }^{34}$ It has been appropriated by different agendas over time and identified or conflated with the interests of a specific copyright constituency. ${ }^{35}$ However, in reality, the public interest in copyright is multidimensional and consists inter alia of authorship interests and access interest. ${ }^{36}$ Although it continues to draw debate about its meaning, the concept of the public interest in copyright remains in usage because of the potential it represents as it evokes the hope of justice and fairness for the common good. ${ }^{37}$ As noted above, this chapter's purpose is not to engage in an excursus of the debates surrounding copyright rhetoric but rather to consider the substantive fairness of licenses for the reprographic reproduction of copyright-protected works. It is to this task, that the rest of the chapter turns.

South African copyright legislation, post-1910, has been based on English law ${ }^{38}$ and is thus imbued with the imperatives of the Statute of Anne and subsequent English legislation. Further, South Africa has ratified both Berne and TRIPS and incorporated their provisions relating to exceptions and limitations, together with other limitations on copyright

\footnotetext{
${ }^{30}$ Caroline B Ncube, 'Harnessing Intellectual Property for Development: Some Thoughts on an Appropriate Theoretical Framework' (2013) 16(4) Potchefstroom Electronic Law Journal 369, 374. A discussion of this question is beyond the scope of this chapter and for present purposes, it will suffice merely to raise it.

${ }^{31}$ Teresa Scassa, 'Interests in the Balance' in Michael Geist ed., In the Public Interest: The Future of Canadian Copyright Law (Irwin Law 2005) 41-65, 41.

32 Patry (supra note 26) 134.

33 For example Drassinower (supra note 26) suggests that dialogue is a more apt term.

34 Isabella Alexander, Copyright Law and the Public Interest in the Nineteenth Century (2010) 16

35 Rebecca Giblin and Kimberlee Weatherall, 'What would copyright law look like if it was actually in the public interest?' Working Paper (2014) 5 -7.

36 Guan H Tang, Copyright and the Public Interest in China (Edward Elgar 2011) 50.

${ }^{37}$ Gillian Davies, Copyright and the Public Interest PhD thesis Aberystwyth University (1997) 1.

38 Tana Pistorius (supra note 19) 148.
} 
into domestic legislation. Therefore, it can also be said that South African copyright law is also fundamentally concerned with the public interest goals of achieving fairness and the balancing of stakeholder interests.

The balancing mechanisms employed by the South African Copyright Act are the same as those adopted globally, which are listed above, and include its provisions for exceptions and limitations. Indeed, three of these provisions - the fair dealing, ${ }^{39}$ quotation ${ }^{40}$ and illustration in teaching ${ }^{41}$ exceptions - expressly refer to fairness. However, the Copyright Act does not provide any guidance as to how the fairness of user conduct is to be assessed. An express stipulation of the relevant factors to be considered in such an assessment would have been beneficial similar to those contained in the United States Copyright Act's fair use provision. ${ }^{42}$ In other common law jurisdictions, such as Canada, which have a fair dealing exception, the courts have pronounced extensively on the relevant factors. However, in South Africa there is no case law elucidating the concept of fairness generally in copyright law or clarifying the contours of the quotation, illustration in teaching and fair dealing exceptions.

In addition to the above exceptions, domesticating Berne article 9(2), s 13 of the South African Copyright Act, provides:

\footnotetext{
${ }^{39}$ Section 12(1) provides 'Copyright shall not be infringed by any fair dealing with a literary or musical work(a) for the purposes of research or private study by, or the personal or private use of, the person using the work;

(b) for the purposes of criticism or review of that work or of another work; or

(c) for the purpose of reporting current events-

(i) in a newspaper, magazine or similar periodical; or

(ii) by means of broadcasting or in a cinematograph film:

Provided that, in the case of paragraphs $(b)$ and $(c)(i)$, the source shall be mentioned, as well as the name of the author if it appears on the work'. (my emphasis)

${ }^{40}$ Section 12(3) provides 'The copyright in a literary or musical work which is lawfully available to the public shall not be infringed by any quotation therefrom, including any quotation from articles in newspapers or periodicals that are in the form of summaries of any work: Provided that the quotations shall be compatible with fair practice, that the extent thereof shall not exceed the extent justified by the purpose and that the source shall be mentioned, as well as the name of the author if it appears on the work.' (my emphasis)

${ }^{41}$ Section 12(4) provides 'The copyright in a literary or musical work shall not be infringed by using such work, to the extent justified by the purpose, by way of illustration in any publication, broadcast or sound or visual record for teaching: Provided that such use shall be compatible with fair practice and that the source shall be mentioned, as well as the name of the author if it appears on the work.' (my emphasis)

${ }^{42}$ Section 107 of the US Copyright Act provides 'Notwithstanding the provisions of sections 106 and 106A, the fair use of a copyrighted work, including such use by reproduction in copies or phonorecords or by any other means specified by that section, for purposes such as criticism, comment, news reporting, teaching (including multiple copies for classroom use), scholarship, or research, is not an infringement of copyright.

In determining whether the use made of a work in any particular case is a fair use the factors to be considered shall include -

(1) the purpose and character of the use, including whether such use is of a commercial nature or is for non profit educational purposes;

(2) the nature of the copyrighted work;

(3) the amount and substantiality of the portion used in relation to the copyrighted work as a whole; and

(4) the effect of the use upon the potential market for or value of the copyrighted work.

The fact that a work is unpublished shall not itself bar a finding of fair use if such finding is made upon consideration of all the above factors.'
} 
In addition to reproductions permitted in terms of this Act reproduction of a work shall also be permitted as prescribed by regulation, but in such a manner that the reproduction is not in conflict with a normal exploitation of the work and is not unreasonably prejudicial to the legitimate interests of the owner of the copyright. The relevant Regulations permit copying of one copy of a reasonable portion of the work, having regard to the totality and meaning of the work and provided 'the cumulative effect of the reproductions does not conflict with the normal exploitation of the work to the unreasonable prejudice of the legal interest and residuary rights of the author' ${ }^{43}$ The issue that this provision raises is: What exactly constitutes a reasonable portion? In other jurisdictions, a quantitative indicator is given which cannot be reduced by a license. For example, the UK's recently amended ${ }^{44}$ Copyright, Designs and Patents Act, 1988 provides that up to ' $5 \%$ of a work may be copied... by or on behalf of an educational establishment in any period of 12 months' ${ }^{45}$ Any license terms that seek to reduce the proportion of a work which may be copied whether subject to a fee or not are void. ${ }^{46}$ South African courts have not pronounced on the extent of what would be considered a reasonable portion, so uncertainty on this point exists.

Two further regulations permit copying, subject to regulation 2, which is quoted above. The first of these, regulation 7, permits the making of 'multiple copies (not exceeding one copy per pupil per course) . . . by or for a teacher for class-room use or discussion'. The second, regulation 8, allows a 'single copy [to] be made by or for a teacher, at his request, for research, teaching or preparation for teaching in a class'. It goes without saying that these two regulations are marred by the uncertainty of regulation 2 to which they cross-refer.

In the absence of clear legislative provisions and judicial guidelines on factors to determine fairness and as to what constitutes a reasonable portion of a work, users are likely to err on the side of caution, to their detriment. ${ }^{47}$ This is probably even more so in the case of 'public-interest institutions like libraries and universities [which] generally stay clear of activities that might bring about litigation' ${ }^{48}$ They are likely to exercise their entitlement to

\footnotetext{
${ }^{43}$ Regulation 2, Copyright Regulations, 1978, GNR.2530 of 22 December 1978.

44 The Copyright and Rights in Performances (Research, Education, Libraries and Archives) Regulations 2014, SI 1372, 2014.

45 Section 36(5).

${ }^{46}$ Section 36(7).

${ }^{47}$ For a discussion of this issue in the context cultural institutions, see E Hudson, Drafting Copyright Exceptions: An Empirical Study (Cambridge Univ. Press 2015) (forthcoming).

48 Chris Armstrong, Jeremy de Beer, Dick Kawooya, Achal Prabhala and Tobias Schonwetter 'Summary and conclusions' in Chris Armstrong et al Access to Knowledge in Africa: The Role of Copyright (UCT Press 2010) $317,322$.
} 
permission-free uses of copyright-protected works to a minimal or negligible extent. It is true that less risk-averse users may liberally interpret the exceptions. However, the fairness of copyright cannot be left to depend on the risk-aversion levels of users.

The lack of certainty as to the extent of permissible license-free use of copyrightprotected works negatively affects the contractual bargaining space because the user approaches negotiations with uncertainty as to the parameters of their permission-free use of the work. Consequently, the resultant licensing agreement may be unfair because it requires the user to pay for uses that should have been permission-free. Such licenses effectively override exceptions and limitations through their failure to take them into account in setting the boundaries of permitted copying or in setting the licensing fee.

To that extent it is reasonable to assert that some unfairness in licensing contracts is due to deficiencies in copyright law. Copyright law can, and should, be amended to change the balance of bargaining positions which would result in fair contracts. There are two kinds of fairness being contemplated here. The first is that the permission free uses of protected works provided for by copyright legislation ought to be fair to the user. If the relevant provisions do not adequately cater for user interests and needs then the playing field is uneven as users start off on the back foot, trying to compensate contractually for legislative shortcomings. This is inherently unfair because contractual uses have to be paid for and in economically disadvantaged contexts, they may become unattainable for those who are unable to afford license fees. Secondly, fairness is being considered in relation to licensing contracts relating to use of the work beyond that permitted by copyright legislation. This aspect is discussed in the second half of this chapter.

The concept of fairness is of significance in relation to the first aspect that of permission free uses of protected works, primarily due its incorporation in the fair dealing, quotation and illustration in teaching exceptions, which have been discussed above. As already stated, the meaning of fairness in these contexts is unclear. To provide the necessary clarity, the Copyright Act ought to be amended to provide for factors that ought to be considered in determining fairness. To this end, lessons can be drawn from the interpretation of similar legislative provisions in other jurisdictions. The Canadian Supreme Court in $\mathrm{CCH}$ Canadian Limited $v$ Law Society of Upper Canada ${ }^{49}$ held that the following factors are to be considered in determining the fairness of the dealing: the purpose of the dealing, the character of the dealing, the amount of the dealing, the nature of the work, available alternatives to the

${ }^{49}[2004] 1$ SCR 339, 2004 SCC 13. 
dealing, and the effect of the dealing on the work. These factors have been consistently applied and were most recently re-iterated by the Supreme Court in $2012 .^{50}$

In addition, the Copyright Act and its Regulations can also be amended to give quantitative guidelines as to permitted reproduction for educational purposes, as has been done in the United Kingdom. As stated above, DALRO has set royalty-free copying parameters at 10 per cent or one chapter of a book for its blanket licenses. This raises the question of whether this constitutes a reasonable portion. The rationale behind setting this limit at 10 per cent rather than any other figure is not publicly available, making it difficult to interrogate it. However, the fact that it sets a fixed limit that does not permit a consideration of individual circumstances engenders some discomfort. Under transactional licenses, license fees are paid for each copy. There is no royalty-free threshold. This raises the question of how the license takes exceptions and limitations into account. In its publications, DALRO asserts that the portions of copyright-protected works that it licenses are not covered by exceptions and limitations. It states:

Finally, it is most important to note that the concessions dealt with above are explicitly stated in Regulation 7 to be intended for "class-room use or discussion ". They do not permit the making of compilations commonly referred to as 'course packs', 'study packs', 'course readers', 'study guides' or 'student hand-outs' in which extracts from various publications are reproduced with or without notes by the lecturer, and then made available to students. ${ }^{51}$

\section{CAN, AND SHOULD, COPYRIGHT EXCEPTIONS AND LIMITATIONS BE OVERRIDDEN BY CONTRACT?}

Exceptions and limitations can be justified on two main grounds, namely fundamental rights and market failure. ${ }^{52}$ Private copying exceptions may be seen as a way of dealing with market failure. ${ }^{53}$ Exceptions for satire, parody, criticism and quotation can be justified on the freedom of expression. ${ }^{54}$ South Africa's Copyright Act currently does not provide for satire

\footnotetext{
${ }^{50}$ Alberta (Education) v Canadian Copyright Licensing Agency (Access Copyright) 2012 SCC 37.

${ }^{51}$ DALRO Reprographic Reproduction of Copyright Material for Educational Purposes 5.

${ }^{52}$ Declaye and Favale (supra note 3 ) 72.

${ }^{53}$ Declaye and Favale (supra note 3) 73.

${ }^{54}$ Section of the 16 Constitution of South Africa, 1996 which provides:

'(1) Everyone has the right to freedom of expression, which includes-

(a) freedom of the press and other media;

(b) freedom to receive or impart information or ideas;

(c) freedom of artistic creativity; and

(d) academic freedom and freedom of scientific research.'
} 
or parody exceptions but provides for fair dealing for purposes of criticism and reporting current events. It is argued that it ought to be amended to provide for parody and satire exceptions to give effect to constitutional imperatives. The Constitutional Court has considered the freedom of expression in a trademark infringement matter ${ }^{55}$ where it was alleged that the parodic use of trademarks tarnished the marks under s 34(1) (c) of the Trademarks Act, 194 of $1993 .{ }^{56}$ The court did not make a finding on fair use of the mark under that section and freedom of expression because it the trademark holder had failed to prove economic harm. ${ }^{57}$ The court noted that:

unlike the US, in our jurisprudence there are no enclaves of protected expression such as parody or satire and therefore the mere characterisation of an expression as such would not be decisive of what is fair use under our anti-dilution protection of section 34(1)(c) because ordinarily all categories of expression, save those excluded by the Constitution itself, enjoy constitutional shield and may be restricted only in a way constitutionally authorised. ${ }^{58}$

The Copyright Act's exceptions for educational purposes clearly can be justified on the constitutionally protected right to education. ${ }^{59}$ It is not possible to exercise this right without access to learning materials. Such access is not entirely dependent on copyright but it is indisputably a key factor. Current copyright law is not optimal for meaningful access to learning materials due to uncertainties such as those pointed out above and its failure to cater for digital and distance learning models, access to orphan works and exceptions to cater for

\footnotetext{
552006 (1) SA 144 (CC). For commentary, see Jason Brickhill, 'Breaking Down the Boardroom Doors with A Snigger and A Smirk - Laugh It Off Laughs Last: Case Note' (2006) 21 SA Public Law 214; J Deacon and I Govender, 'Trade Mark Parody in South Africa - The Last Laugh!' (2007) 32 Journal for Juridical Science 18; George Devenish, 'We are Amused: Laugh it Off Promotions CC v SAB International (Finance) BV t/a Sabmark International: notes' (2005) 122 SALJ 792; Tana Pistorius 'Trade-mark Tarnishment: Should We "'Laugh it Off'” All the Way to “Telkomsucks"' and 'Hellcom'??' (2004) 16 SA Merc LJ 727; and C Ncube, 'From the law reports: Laugh It Off Promotions CC v South African Breweries International (Finance) BV t/a Sabmark International' 2005 (1) Codicillus 82.

56 The section provides:

'The rights acquired by registration of a trade mark shall be infringed by-the unauthorised use in the course of trade in relation to any goods or services of a mark which is identical or similar to a trade mark registered, if such trade mark is well known in the Republic and the use of the said mark would be likely to take unfair advantage of, or be detrimental to, the distinctive character or the repute of the registered trade mark, notwithstanding the absence of confusion or deception: Provided that the provisions of this paragraph shall not apply to a trade mark referred to in section 70(2)'. 57 At para 65.

58 Ibid.

${ }^{59}$ Section 29 of the Constitution of South Africa, 1996 provides: 'Everyone has the right to a basic education, including adult basic education and further education, which the State, through reasonable measures, must progressively make available and accessible'.
} 
the conversion of works to formats that are accessible to the visually impaired. ${ }^{60}$ Despite such limitations, these exceptions are so crucial to achieving access to learning materials that South Africa cannot continue to risk them being overridden by contract. In addition, if they were strengthened in the future, one would want them to be protected from abrogation by agreement.

There is support for the view that exceptions and limitations based on fundamental rights ought to be imperative and thereby protected from contractual abrogation. Indeed, some jurisdictions make exceptions and limitations imperative and nullify any contractual clauses that seek to reduce or minimise them. The examples cited by Declaye and Favale ${ }^{61}$ of such jurisdictions are Belgium, ${ }^{62}$ Ireland $^{63}$ and Portugal. ${ }^{64}$

The approach of these jurisdictions has been faulted for making all exceptions and limitations mandatory, rather than protecting only those relating to fundamental rights and public policy. ${ }^{65}$ Hence the suggestion in that not all exceptions and limitations be made imperative but that careful choices must be made about which of them to make imperative. It is argued that this critique is assailable because as all exceptions and limitations have a justiciable public interest basis, they should be mandatory. Exposing some or all of tem to contractual arbitrage would not be in the public interest.

Currently there are no provisions in the South African Copyright Act that invalidate any contractual clauses that attempt to override such exceptions and limitations. It would therefore appear that contractual clauses might reduce or eliminate them altogether. The following section of this chapter considers whether, in the face of the inadequacy of copyright law, South African users can look to consumer protection law for any protection. At the outset, it is important to note that resorting to consumer protection law is an acceptable alternative, which has been lauded by some because it is a body of law that aims to "promote and advance the social and economic welfare of consumers' ${ }^{66}$ For example, Consumers International has identified the use of consumer protection law to prohibit or reduce the

\footnotetext{
${ }^{60}$ Caroline B Ncube 'Key copyright issues in African distance education: a South African case study' (2011) 32(2) Distance Education 269; Tobias Schonwetter and Caroline B Ncube, 'New hope for Africa? Copyright and access to knowledge in the digital age' (2011) 13(3) Info 64-74; Tobias Schonwetter, Caroline B Ncube and Pria Chetty 'South Africa Country Report' in Chris Armstrong et al (ed.) Access to Knowledge in Africa: The Role of Copyright (2010) UCT Press, 231-280.

${ }^{61}$ (supra note 3) 83-87.

${ }^{62}$ Art 11 of the Belgian Database Act, Law 31 of 1998 makes all exceptions relating to the sui generis database right imperative and art 23 bis makes similar provision in relation to copyright exceptions.

${ }^{63}$ s2(10) Copyright Act n.38 of 2000.

${ }^{64}$ Code of Author's Rights and Related Rights, 14 March 1985.

${ }^{65}$ Declaye and Faye (supra note 3) 84.

${ }^{66}$ Section 3(1) Consumer Protection Act.
} 
exclusion of user rights as a best practice because it provides avenues of redress 'against big companies that use their IP to infringe upon consumers' rights. ${ }^{, 67}$

\section{FAIRNESS UNDER THE CONSUMER PROTECTION ACT}

\section{Applicability of Consumer Protection Legislation to Copyright Licenses}

The South African Consumer Protection Act, 2008 came into force in April 2011. It 'applies to every transaction ${ }^{68}$ occurring within South Africa, which has not been exempted by the Act, and to the promotion and supply of any goods or services within South Africa'. Goods are defined as 'any literature, music, photograph, motion picture, game, information, data, software, code or other intangible product written or encoded on any medium, or a license to use any such intangible product'. These are copyright-eligible goods and copyright will subsist automatically in them if the three requirements for protection are met, namely that the work original, ${ }^{69}$ it is reduced to a material form ${ }^{70}$ and is created by a qualified person ${ }^{71}$ or is first published in South Africa or another country to which protection is extended. ${ }^{72}$

The Consumer Protection Act will not apply to contracts, which pertain to these goods if any exemptions apply. The relevant exemptions are: ${ }^{73}$

1. transactions under which goods and services are promoted or supplied to the state, and

2. transactions where the consumer is a juristic person that had an annual turnover of more than ZAR 2 million at the time of the transaction.

The second exemption is subject to the exception that juristic persons, regardless of turnover, are entitled to benefit for the protection provided for in sections 60 -61 of the Act, which pertain to product recalls. ${ }^{74}$ These exemptions are quite significant. They would apply where a government department (that is the state) or an institution of higher education which has an

${ }^{67}$ Consumers International IPWatchlist 2012, 4.

${ }^{68}$ Defined by s1 as-

'(a) in respect of a person acting in the ordinary course of business-

(i) an agreement between or among that person and one or more other persons for the supply or potential supply of any goods or services in exchange for consideration; or

(ii) the supply by that person of any goods to or at the direction of a consumer for consideration; or

(iii) the performance by, or at the direction of, that person of any services for or at the direction of a consumer for consideration; or

(b) an interaction contemplated in section 5 (6), irrespective of whether it falls within paragraph (a).'

${ }^{69}$ Section 2(1) Copyright Act.

${ }^{70}$ Section 2(2) Copyright Act.

${ }^{71}$ Section 3(1) Copyright Act.

${ }^{72}$ Section 4(1) Copyright Act.

73 Section 5(2) (a) - (b) Consumer Protection Act.

${ }^{74}$ Elizabeth de Stadler Consumer Law Unlocked (2013) 8. 
annual turnover that is above the above-stated threshold enters into licensing contract with regard to the reprographic reproduction of books. This means that any normative regulation of contracts provided for in the Consumer Protection Act will not apply. They would only apply where the educational institution has an annual turnover of less than ZAR 2 million.

The applicability of consumer protection legislation to copyright-protected goods distinguishes South Africa from the United Kingdom, where the Unfair Contract Terms Act 1977 and its regulations do not apply to copyright contracts which create or transfer rights or an interest. ${ }^{75}$ Another distinction between the two jurisdictions is that the Unfair Contract Terms Act focuses on limitation clauses in pro forma or standard form contracts, whereas the South African Consumer Protection Act is much broader in its ambit. It also considers unfairness in contracts that have been negotiated by the parties. To that extent, its approach is closer to Australian Consumer Law (ACL). ${ }^{76}$ In particular, ACL regulates 'misleading and deceptive conduct, unconscionable conduct, unfair practices, consumer guarantees, unsolicited consumer agreements and consumer product safety'. ${ }^{77}$ All these aspects are also covered by South African consumer protection legislation.

\section{Normative Regulation of Fairness}

The concept of fairness is well developed in South African contract ${ }^{78}$ and consumer protection law, where it has a multi-dimensional character which addresses substantive, procedural, abstract and contextual fairness. ${ }^{79}$ Existing statutory provisions seek to achieve a balance between contractual parties' freedom of choice and the need to eliminate or reduce inequities due to the differences in the parties' bargaining power, knowledge of the law and their ability to enforce their rights.

\footnotetext{
${ }^{75}$ Schedule 1, s1(c) provides that Sections 2 to 4 of the Act do not extend to 'any contract so far as it relates to the creation or transfer of a right or interest in any patent, trade mark, copyright, registered design, technical or commercial information or other intellectual property, or relates to the termination of any such right or interest'. ${ }^{76}$ Schedule 2 Competition and Consumer Act 2010.

77 Jeannie Paterson Unfair Contract Terms in Australia (Thompson Reuters 2012) 11.

${ }^{78}$ For example, see AM Louw, 'Yet Another Call for a Greater Role For Good Faith in the South African Law of Contract: Can We Banish the Law of the Jungle, While Avoiding the Elephant in the Room?' (2013) 16(5) Potchefstroom Electronic Law Journal 44; Philip J Sutherland, 'Ensuring contractual fairness in consumer contracts after Barkhuizen v Napier 20075 SA 323 (CC) - part 1' (2008) 19(3) Stellenbosch Law Review 390; Philip J Sutherland, 'Ensuring contractual fairness in consumer contracts after Barkhuizen v Napier 20075 SA 323 (CC) - part 2' (2009) 20 Stellenbosch Law Review 50.

79 Philip N Stoop, The Concept of 'Fairness' in the Regulation of Contracts under the Consumer Protection Act 68 of 2008, Thesis LLD University of South Africa, 2012, 32-49.
} 
The South African Consumer Protection Act seeks to provide protection for consumers ${ }^{80}$ in accordance with its stated purposes and policy. ${ }^{81}$ For this chapter, the most relevant purpose is:

protecting consumers from-

(i) Unconscionable, unfair, unreasonable, unjust or otherwise improper trade practices; and

(ii) deceptive, misleading, unfair or fraudulent conduct (my emphasis) ${ }^{82}$

This chapter focuses on substantive fairness. ${ }^{83}$ The goal of substantive fairness is achieved through a number of statutory provisions. The most pertinent of these for this discussion is use of black lists, which prohibit certain clauses and render them void ab initio, and grey lists, which create a rebuttable presumption that other clauses are unfair, unreasonable or unjust. The black list is contained in s 51 of the Act and the grey list is contained in reg 44 of the Regulations. ${ }^{84}$ A full discussion of the use of these lists is beyond the ambit of this chapter and readers are referred to other writing on these points. ${ }^{85}$ Section 48 of the Act contains the 'general fairness criterion for consumer contracts ${ }^{86}$ that is also referred to as 'the general right to fairness'. 87

The threefold approach of s 48 (1) is of particular relevance to this discussion First, s 48(1) (a) prohibits the inclusion of unfair, unreasonable or unjust terms in contracts. It provides:

A supplier must not offer to supply, supply, or enter into an agreement to supply, any goods or services at a price that is unfair, unreasonable or unjust; or on terms that are unfair, unreasonable or unjust.

${ }^{80}$ Defined by s1 'in respect of any particular goods or services' as:

'(a) a person to whom those particular goods or services are marketed in the ordinary course of the supplier's business;

(b) a person who has entered into a transaction with a supplier in the ordinary course of the supplier's business, unless the transaction is exempt from the application of this Act by section 5 (2) or in terms of section 5 (3); (c) if the context so requires or permits, a user of those particular goods or a recipient or beneficiary of those particular services, irrespective of whether that user, recipient or beneficiary was a party to a transaction concerning the supply of those particular goods or services; and

(d) a franchisee in terms of a franchise agreement, to the extent applicable in terms of section 5 (6) (b) to (e).' 81 s 3 .

82 s 3(1) (d).

${ }^{83}$ The reader is referred elsewhere for a nuanced discussion of the other related concepts such as unconscionability which goes to procedural fairness. For example, see Graham Glover, 'Section 40 of the Consumer Protection Act in Comparative Perspective' (2013) 4 TSAR 289; Jacques Du Plessis, 'Protecting consumers against unconscionable conduct: Section 40 of the Consumer Protection Act 68 of 2008' (2012) THRHR 26.

84 Consumer Protection Regulations, GNR.293 of 1 April 2011: Regulations (Government Gazette No. 34180).

85 Tjakie Naudé, 'The use of black and grey lists in unfair contract terms legislation in comparative perspective' (2007) 124 South African Law Journal 128.

${ }^{86}$ Stoop (supra note 56) 113.

87 De Stadler (supra note 77) 114. 
Secondly, s 48(1) (b) prohibits the marketing of any goods or services, or the negotiation, conclusion or administration of a transaction or an agreement in a manner that is unfair, unreasonable or unjust. Thirdly, s 48(1) (c) prohibits suppliers from requiring 'a consumer, or other person to whom any goods or services are supplied at the direction of the consumer, to waive any rights; assume any obligation; or waive any liability of the supplier, on terms that are unfair, unreasonable or unjust, or impose any such terms as a condition of entering into a transaction.'

The Consumer Protection Act then sets out a list of unfair, unreasonable or unjust transactions or agreements, terms or conditions and notices which includes the following: ${ }^{88}$ (a) 'excessively one-sided in favour of any person other than the consumer or other person to whom goods or services are to be supplied'; and

(b) 'so adverse to the consumer as to be inequitable.'

One may argue that clauses in licensing agreements that override, or take no account of exceptions and limitations in setting license fees, are unreasonable, unfair and unjust because they render the contract excessively one-sided in favour of the licensor and are so adverse to the licensee as to be inequitable. In addition one could argue that licensors who conclude such contracts have not negotiated in good faith. Such an argument should stand despite the lack of provisions in the Copyright Act that make such exceptions imperative. This is because of the constitutional imperatives that underpin some exceptions, such as the right to education and freedom of expression which have been briefly canvassed above.

These two factors - (a) and (b) - above are the substantive equivalent of Regulation 5(1) in the UK Unfair Terms in Consumer Contracts Regulations, which refer to terms that cause 'a significant imbalance in the parties' rights and obligations under the contract to the detriment of the consumer'. ${ }^{89}$ Accordingly, an assessment of the entire contract in question would be necessary to weigh rights and obligations of both parties to ascertain if an excessive imbalance exists. There is as yet no case law in South Africa on this point relating to copyright user contracts. For its part, DALRO reports that it has reviewed its licenses to ensure compliance with the Consumer Protection Act. ${ }^{90}$

There certainly seems to be scope to challenge unfair blanket and transactional licenses on the basis of consumer protection law. However, the statutory provisions are not

\footnotetext{
${ }^{88}$ s 48(2).

${ }^{89}$ Stoop (supra note 56) 115, citing Director General of Fair Trading v First National Bank [2002] 1 Lloyd's Rep 489; [2001] 3 WLR 1297 and Sasfin (Pty) Ltd v Beukes 1989 (1) SA 1 (A).

90 DALRO Annual Report, 2011 < http://www.dalro.co.za/index.php/about-us > (last assessed on November 2013).
} 
applicable where the licensee has a turnover of more than ZAR 2 million, and would thus exclude many institutions of higher learning and perhaps some government departments that take out licenses on behalf of schools. In order to mount a successful challenge, it would be necessary to prove that exceptions and limitations have been unfairly discounted in setting license terms and fees and, consequently, the resultant contract is either excessively onesided or is so adverse that it is inequitable.

However, to the extent that some inequities are due to the inadequacy of current copyright law, is it necessary to effect some amendments of copyright law to broaden and entrench exceptions and limitations. This underscores the lex specialis nature of copyright, which defines the baseline for both right-holders and users. The need to return to the baseline is inevitable because doing so will benefit all users and particularly those who are excluded from the ambit of the Consumer Protection Act. 